\title{
UPAYA MENINGKATKAN PEMAHAMAN KONSEP DAN DISPOSISI MATEMATIS MENGGUNAKAN MODEL PEMBELAJARAN TREFFINGER DI SMA NEGERI 1 ANGKOLA BARAT
}

\author{
Benny Sofyan Samosir ${ }^{1)}$; Andes Fuady ${ }^{2)}$ \\ ${ }^{1)}$ Pendidikan Matematika, FKIP Universitas Muhammadiyah Tapanuli Selatan \\ ${ }^{2)}$ Pendidikan Ekonomi, FKIP Universitas Muhammadiyah Tapanuli Selatan \\ bennysofyansamosir@um-tapsel.ac.id
}

\begin{abstract}
This type of research is Class Action Research. Where the subject of the research is the grade $\mathrm{X}_{5}$ SMA Negeri 1 Angkola West which consists of 38 students. While the techniques and tools to capture data that is now, tests and observations. The percentage of students on mathematical disposition now cycle I was $50.26 \%$ to $81.57 \%$ in cycle II. With the amount of the percentage increase in students ' mathematical disposition of $31.31 \%$. Understanding of the mathematical concepts of students increases, it is retrieved from the percentage of the cycle I $52.63 \%$ become $81.39 \%$ in cycle II, students and the amount of the percentage rose $28.94 \%$. Students learn math activity increases; it is retrieved from $63.98 \%$ percentage of the cycle I and $63.98 \%$ in cycle II. With the amount of the percentage increase in the activity of students of $22.94 \%$. The ability of the teacher to manage learning percentage amounted to $64.00 \%$ in cycle I and cycle II $83.00 \%$, with an increase of $19.00 \%$. The results of this study showed that the learning model Treffinger might improve the understanding of mathematical concepts and disposition of the students of class $\mathrm{X}_{5}$ SMA Negeri 1 Angkola West.
\end{abstract}

Keywords: The Learning Model Treffinger, understanding Mathematical concepts, Dispositions, SPLDV.

\begin{abstract}
Abstrak
Jenis penelitian ini adalah Penelitian Tindakan Kelas (classroom research). Dimana subjek penelitian adalah siswa kelas $\mathrm{X}_{5}$ SMA Negeri 1 Angkola Barat yang terdiri dari 38 orang siswa. Sedangkan teknik dan alat pengumpul data yaitu angket, tes dan observasi. Persentase angket disposisi matematis siswa pada siklus I adalah 50,26\% menjadi $81,57 \%$ pada siklus II. Dengan jumlah persentase peningkatan disposisi matematis siswa sebesar $31,31 \%$. Pemahaman konsep matematika siswa meningkat, hal ini diperoleh dari presentase pada siklus I 52,63\% menjadi $81,39 \%$ pada siswa siklus II, dan jumlah persentase naik $28,94 \%$. Aktivitas belajar matematika siswa meningkat, hal ini diperoleh dari persentase 63,98\% pada siklus I dan 63,98\% pada siklus II. Dengan jumlah persentase peningkatan aktivitas siswa sebesar 22,94\%. Kemampuan guru mengelola pembelajaran presentase sebesar $64,00 \%$ pada siklus I dan $83,00 \%$ pada siklus II, dengan peningkatan sebesar $19,00 \%$. Hasil penelitian ini memperlihatkan bahwa model pembelajaran Treffinger dapat meningkatkan pemahaman konsep dan disposisi matematis siswa kelas $\mathrm{X}_{5}$ SMA Negeri 1 Angkola Barat.
\end{abstract}

Kata Kunci: Model pembelajaran Treffinger, Pemahaman Konsep, Disposisi Matematis, SPLDV.

PeTeKa (Jurnal Penelitian Tindakan Kelas dan Pengembangan Pembelajaran) $\mid 54$ 


\section{PENDAHULUAN}

Kemampuan pemahaman siswa
disekolah terhadap materi yang
diajarkan belum sepenuhnya tergali
dengan baik dikarenakan banyak faktor
yang membuat kemampuan siswa tidak
berkembang secara baik. Oleh karena
itu kemampuan pemahaman siswa
disekolah harus ditingkatkan.
Pemahaman merupakan aspek kemampuan siswa yang termasuk ke dalam Cognitive Domain (ranah kognitif). Ranah kognitif berisi perilaku-perilaku yang menekankan aspek intelektual, seperti pengetahuan, pengertian, dan keterampilan berpikir

Pemahaman berasal dari kata paham yang artinya mengerti benar dalam suatu hal. Menurut Sudijono (2008) menyatakan bahwa pemahaman adalah kemampuan seseorang untuk mengerti atau memahami sesuatu setelah sesuatu itu diketahui dan diingat. Seorang peserta didik dikatakan memahami sesuatu apabila ia dapat memberikan penjelasan atau member uraian lebih rinci tentang hal itu dengan menggunakan kata-katanya sendiri..Untuk dapat mencapai tahap pemahaman terhadap suatu konsep matematika siswa harus mempunyai pengetahuan terhadap konsep tersebut.

Sejalan dengan hal di atas Depdiknas (2003) mengungkapkan bahwa, pemahaman konsep merupakan salah satu kecakapan atau kemahiran matematika yang diharapkan dapat tercapai dalam belajar matematika yaitu dengan menunjukkan pemahaman konsep matematika yang dipelajarinya, menjelaskan keterkaitan antar konsep dan mengaplikasikan konsep atau algoritma secara luwes, akurat, efisien, dan tepat dalam pemecahan masalah.

Sumarmo (2010) mendefenisikan disposisi matematis (mathematical disposition) yaitu keinginan, kesadaran, kecenderungan dan dedikasi yang kuat pada diri siswa atau mahasiswa untuk berpikir dan berbuat secara matematika.Terdapat hubungan yang kuat antara disposisi matematis dan pembelajaran.Pembelajaran matematika di kelas harus dirancang khusus sehingga selain dapat meningkatkan prestasi belajar siswa juga dapat meningkatkan disposisi matematis.

Wardani (2009) mendefinisikan disposisi matematis sebagai suatu ketertarikan dan apresiasi terhadap matematika seperti kecenderungan untuk berpikir dan bertindak dengan positif termasuk kepercayaan diri, keingintahuan, ketekunan, antusias dalam belajar, gigih dalam menghadapi permasalahan, fleksibel, mau berbagi dengan orang lain dan reflektif dalam kegiatan matematika. Disposisi matematis berkaitan dengan bagaimana siswa menyelesaikan masalah matematis, apakah mereka menyelesaikannya dengan penuh rasa percaya diri, tekun, berminat, dan berpikir fleksibel untuk menemukan berbagai alternatif penyelesaian masalah.

Menurut Shoimin (2014) model Treffinger untuk mendorong belajar kreatif menggambarkan susunan tiga tahap yang mulai dengan unsur-unsur dasar dan menanjak ke fungsi-fungsi berpikir yang lebih majemuk, siswa terlibat dalam kegiatan membangun keterampilan pada dua tahap pertama untuk kemudian menangani masalah kehidupan nyata pada tahap ketiga. Strategi model pembelajaran Treffnger dikembangkan dari model belajar kreatif yang bersifat developmental dan mengutamakan segi proses. Strategi pembelajaran yang dikembangkan Treffinger yang berdasarkan kepada model belajar kreatifnya.

Menurut Ngalimun, (2014) pembelajaran kreatif dengan basis 
Benny Sofyan Samosir, dkk. Upaya Meningkatkan Pemahaman Konsep Dan ...

kematangan dan pengetahuan siap dengan sintaks: keterbukaan-urutan idepenguatan, penggunaan ide kreatifkonflik internal-skill, proses rasa-pikir kreatif dalam pemecahan masalah secara mandiri melalui pemanasanminat-kuriositi-tanya, kelompokkerjasama, kebebasan-terbuka, reward.

Dari uraian di atas, penulis mendeskripsikan hasil Penelitian Tindakan Kelas (PTK) Meningkatkan Pemahaman Konsep Dan Disposisi Matematis Menggunakan Model Pembelajaran Treffinger Di SMA Negeri 1 Angkola Barat.

\section{METODE}

Penelitian ini dilaksanakan di kelas $\mathrm{X}_{5}$ SMA Negeri 1 Angkola Barat, waktu penelitian ini dilaksanakan pada tanggal 06 Mei 2017 s/d 10 Agustus 2017.

Subjek dalam penelitian ini adalah siswa kelas $\mathrm{X}_{5}$ SMA Angkola Barat yang terdiri dari 38 siswa, terdiri dari 13 siswa laki-laki dan 25 siswa perempuan.

Jenis Penelitian ini adalah penelitian tindakan kelas. Prosedur penelitian tindakan kelas ini terdiri dari 2 siklus, setiap siklus terdiri dari dua kali pertemuan melalui empat tahapan, yaitu :

(1)Perencanaan

Kegiatan yang dilakukan pada tahap ini yaitu :

(a)Membuat Rencana Pelaksanaan pembelajaran (RPP) dengan model pembelajaran Treffinger.

(b)Menyusun dan mempersiapkan lembar observasi mengenai pelaksanaan pembelajaran matematika menggunakan model pembelajaran Treffinger.

(c)Mempersiapkan Lembar Kegiatan Siswa (LKS) sebagai media untuk meningkatkan pemahaman konsep dan disposisi matematis siswa.

(2)Pelaksanaan

Pelaksanaan tindakan

merupakan implementasi dari perencanaan. Pelaksanaan tindakan dilakukan pada proses pembelajaran secara terstruktur sesuai dengan rencana pelaksanaan pembelajaran (RPP) dan memberikan LKS, dengan menerapkan strategi pembelajaran model Treffinger sesuai denganrencana pelaksanaan pembelajaran (RPP).

(3)Refleksi

Obsevasi dilakukan dengan mengamati secara langsung bagaimana aktivitas siswa selama proses belajar mengajar. Pada saat observasi dilaksanakan peneliti telah mempersiapkan lembar observasi, guna mengetahui keterlaksanaan pembelajaran dengan menggunankan model Treffinger. Dalam penelitian tindakan kelas, pengamatan/ observasi yang dilaksanakan dalam beberapa aspek yang diamati adalah sebgai berikut:

(a)Pengamatan terhadap siswa.

(b)Pengamatan terhadap guru.

(4)Refleksi

Refleksi dilakukan setelah akhir siklus. Hal tersebut bertujuan untuk mengevaluasi hasil tindakan yang dilakukan yaitu dengan cara melakukan penilaian terhadap proses yang terjadi, masalah yang muncul dan segala hal yang berkaitan dengan tindakan yang dilakukan. Setelah itu peneliti merumuskan tindakan berikutnya dan apabila berdasarkan refleksi perlu dilaksanakan pengulangan siklus maka dapat diulang lagi sampai pembelajaran telah optimal.

Kegiatan yang dilakukan pada tahap ini adalah:

(a)Menganalisa dan memberikan arti terhadap data yang diperoleh , memperjelas data, sehingga dapat 
diambil kesimpulan dari tindakan yang telah diberikan.

(b)Hal yang dilakukan pada refleksi adalah mengulas balik terhadap perangkat pembelajaran dan aktivitas siswa dalam pembelajaran.

(c)Hasil refleksi ini kemudian digunakan sebagai dasar siklus berikutnya.

(d)Merancang tindakan yang diperlukan untuk siklus selanjutnya

Siklus penelitian ini dianggap berhentiapabila kriteria ketuntasan sudah mencapai $80 \%$.

\section{Analisis Data}

\section{(a)Analisis Data Observasi Guru}

Mencari presentase rata - rata frekuensi setiap kategori aktivitas guru yaitu membagi rata - rata frekuensi untuk setiap kategori dengan banyak frekuensi pengamatan untuk tiap - tiap pertemuan, kemudian hasil pembagian dikalikan dengan 100\%.Dapat dirumuskan sebagai berikut :

Presentase Aktivitas Guru = $\frac{\text { jumlah rata-rata frekuensi pengamatan }}{\text { jumlahbanyak frekuensi pemgamatan }} x$ $100 \%$

(b)Analisis Data Observasi Siswa

- Menganalisis data semua aktivitas siswa pada setiap akhir pertemuan

- Menghitung berapa banyak siswa yang melakukan aktivitas pada langkah pembelajaran Treffinger.

- Menghitung persentase siswa yang melakukan aktivitas pada langkah pembelajaran Treffinger.

Presentase aktivitas siswa $=$ $\underline{\text { jumlah siswa yang melakukan aktivitas }} \times$ $100 \%$ (c) Analisis data tes pemahaman konsep matemtika siswa pada materi Sistem Persamaan Linear Dua Variabel

Setelah data tes pemahaman konsep matematika siswa melalui penerapan langkah-langkah model pembelajaran Treffinger, diperoleh data disajikan dalam tabel distribusi frekuensi. Untuk menjawab permasalahan dalam penelitian ini dilakukan langkah -langkah sebagai berikut :

a. Untuk mengetahui kemampuan siswa sebelum diberi tindakan peneliti akan menggunakan tes diagnostik, tujuannya mengetahui seberapa besar tingkat pemahaman konsep siswa dalam belajar matmatika.

b. Untuk mengetahui kemampuan siswa setelah diberi tindakan.Setelah model pembelajaran Treffinger digunakan dalam materi SPLDV, maka peneliti akanmemberi tes disetiap akhir siklus, tujuannya untuk mengetahui peningkatan pemahaman konsep siswa.

c. Untuk mengetahui besarnya persentase peningkatan kemampuan siswa pada pokok materi SPLDV.

Peneliti menggunakan rumus:

$$
\mathrm{NP}=\frac{R}{S M} \times 100 \%
$$

Keterangan:

$\mathrm{NP}=$ Nilai persen yang dicari (dalam persen)

$\mathrm{R}=$ Skor mentah yang diperoleh siswa $\mathrm{SM}=$ Skor maksimum ideal dari tes yang bersangkutan

(d)Analisis angket Disposisi Matematis Hasil angket disposisi matematis siswa dianalisis dengan langkahlangkah yaitu : 
Benny Sofyan Samosir, dkk. Upaya Meningkatkan Pemahaman Konsep Dan ...

- Menghitung skor setiap butir pernyataan sesuai dengan pedoman dan kriteria yang telah ditetapkan.

- Mengelompokkan setiap butir pernyataan sesuai aspek disposisi matematik yang telah dirumuskan.

- Menghitung jumlah skor tiap butir pernyataan selanjutnya menghitung skor akhir disposisi matematis siswa dengan cara mengubah skor yang diperoleh menjadi skor berstandar $\quad 100 \quad$ dengan menggunakan rumus sebagai berikut :

Skor akhir $=$

jumlah skor angket yang diperoleh peset didik $x$ $100 \%$ jumlah skor angket maksimal

- Skor akhir angket disposisi yang diperoleh selanjutnya dikelompokkan dengan ketentuan yang terdapat dalam tabel berikut ini.

\section{HASIL DAN PEMBAHASAN}

Berdasarkan hasil observasi pada siklus I guru dan siswa telah melakukan kegiatan pembelajaran yang sesuai dengan model pembelajaran Treffinger namun masih dapat kekurangankekurangan. Dimana kekurangan itu pada yang berasal pada guru dan juga berasal dari siswa. Diantaranya sebagaimana siswa yang tidak memperhatikan penjelasan pada saat guru menyampaikan materi dan kekurangan yang berasal dari guru adalah belum terlaksananya semua komponen dalam skenario pembelajaran.

Hal ini karena guru belum dapat mengatur waktu sebaik mungkin. Guru terlalu banyak memberikan waktu pada siswa untuk bekerja menyelesaiakan soal-soal yang diberikan dan guru masih canggung dan belum terbiasa dengan model pembelajaran Treffinger. Melihat kekurangan yang masih ada pada pemahaman konsep matematika siswa pada siklus I belum memenuhi indikator keberhasilan yang ditetapkan. Maka penelitian ini lanjut pada siklus II adalah guru harus selalu membimbing dan mengarah siswa dalam belajar untuk meningkatkan kreativitas belajar siswa.

Kemudian keberhasilan pada siklus II ini dapat dilihat dari hasil observasi aktivitas guru yang dilakukan setiap siklusnya dapat dilihat hasilnya yaitu siklus I memperoleh persentase 64 $\%$ dan pada siklus II guru lebih meningkat menjadi $83 \%$. Dilihat dari indikator keberhasilan maka guru mengalami peningkatan, dan hal ini pada siklus II telah mencapai indikator keberhasilan, maka peniliti memberhentikan penelitian pada siklus II. Dilihat dari hasil observasi aktivitas siswa juga mengalami peningkatan, dimana siklus I memperoleh persentase $63,98 \%$ dan siklus II memperoleh $86,92 \%$ dilihat dari hasil tersebut data observasi aktivitas siswa mengalami peningkatan. Untuk lebih jelas dapat dilihat pada diagram berikut:

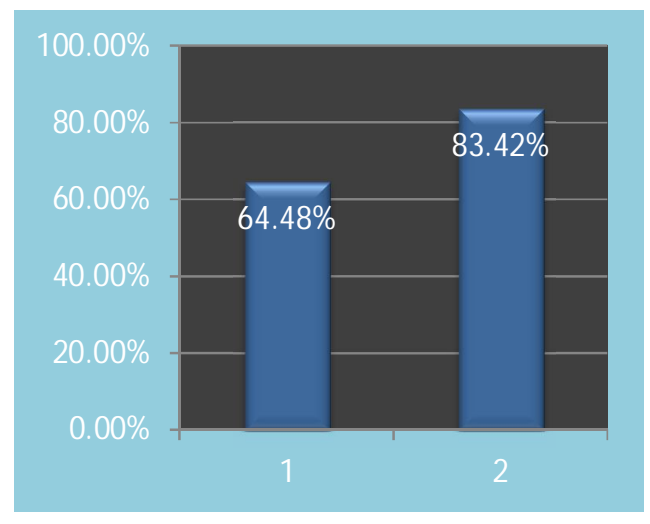

Gambar 1: Peningkatan Aktivitas Guru

Melalui model pembelajaran Treffinger pemahaman konsep dan disposisi matematis siswa dapat meningkat khusus nya pada materi 
SPLDV setelah proses pembelajaran selesai maka siswa diberikan tes essay sebanyak 5 soal tiap-tiap siklusnya. Dan hasil tersebut meliputi pada siklus I memperoleh 52,63\%. Karena hasil belajar matematika belum mencapai indikator keberhasilan, maka pembelajaran dilanjutkan pada siklus II. Setelah pembelajaran siklus II maka siswa kembali diberikan tes berbentuk essay sebanyak 5 soal kepada siswa yang memperoleh persentase $81,57 \%$. Peningkatan pemahaman konsep siswa dapat dilihat pada tabel dibawah ini :

Tabel1: Peningkatan Hasil Belajar
Siswa

\begin{tabular}{ccc}
\hline No & Kegiatan & $\begin{array}{c}\text { Persentase } \\
\text { Ketuntasan }\end{array}$ \\
\hline $\mathbf{1}$ & Siklus I & $52,63 \%$ \\
$\mathbf{2}$ & Siklus II & $81,57 \%$. \\
\hline
\end{tabular}

Dari tabel diatas dapat dilihat persentase peningkatan hasil evaluasipemahaman konsep siswa setiap siklusnya. Berdasarkan data- data diatas maka peningkatan tes hasil belajar siswa juga dapat dilihat melalui grafik berikut ini:

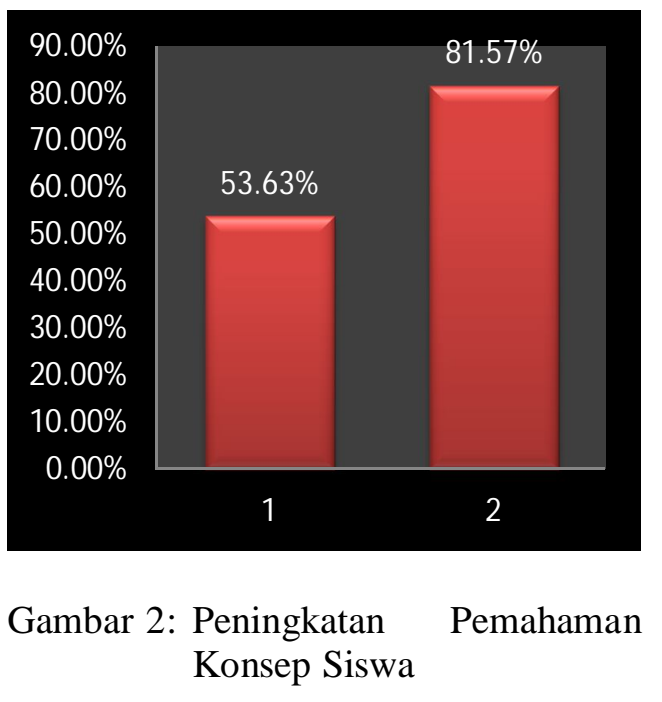

Selain tes hasil belajar siswa diatas, keberhasilan peningkatan siswa dari siklus I ke siklus II dapat dilihat juga berdasarkan hasil angket, penelitian setelah diberikan tindakan pada siklus I dan siklus II menjadi lebih terlatih menyusun langkah - langkah model pembelajaran Treffinger. Berdasarkan hasil angket yang diperoleh pada siklus I sebesar 50,26 $\%$ dan pada siklus II meningkat menjadi $81,57 \%$ karena pada siklus II ini telah mencapai indikator maka peneliti memberhentikan penelitian ini pada siklus II. Dari persentase angket disposisi mtematis siswa pada siklus I dan siklus II tersebut dapat dilihat pada grafik berikut ini :

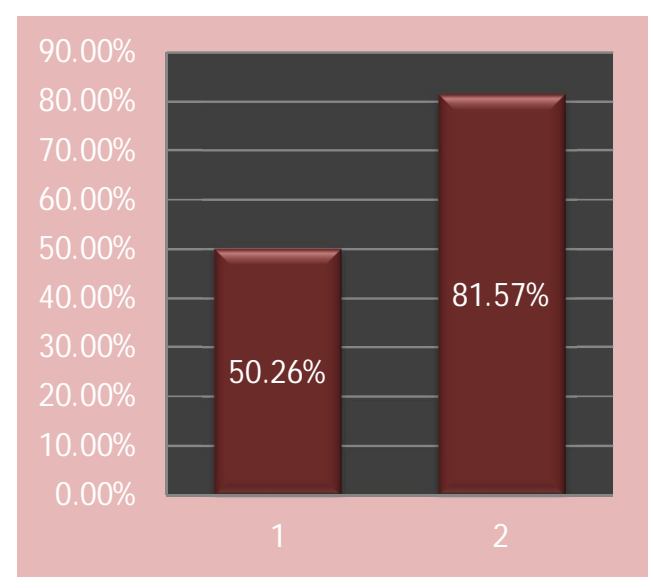

$\begin{aligned} \text { Gambar 3: Peningkatan } & \text { Disposisi } \\ & \text { Matematis Siswa }\end{aligned}$

Dari gambar grafik diagram diatas dapat dijelaskan bahwa persentase angket disposisi matematis siswa siklus I sebesar 50,26 \%dan belum mencapai indikator yang ditentukan yaitu $80 \%$, maka penelitian ini dilanjutkan pada siklus II yang memperoleh persentase sebesar $81,57 \%$ dan telah memenuhi indikator yang ditentukan maka penelitian ini diberhentikan pada siklus II ini. 
Benny Sofyan Samosir, dkk. Upaya Meningkatkan Pemahaman Konsep Dan ...

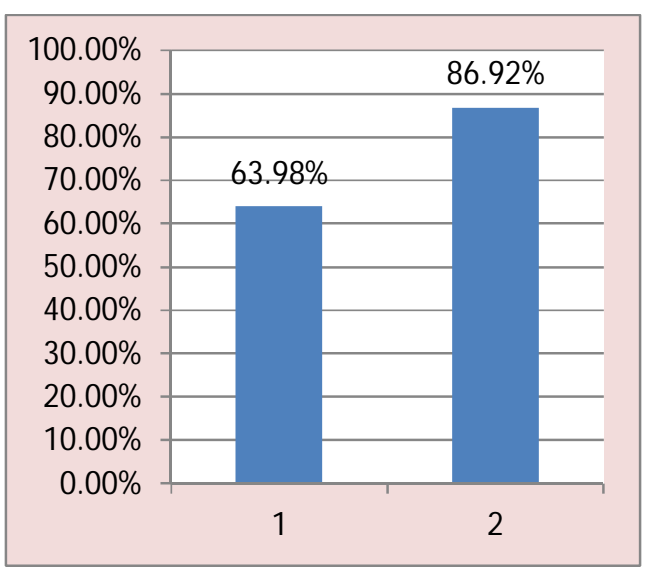

Gambar 4: Peningkatan Aktivitas Siswa

Dalam proses belajar mengajar
dengan menerapkan model pembelajaran Treffinger ini aktivitas belajar siswa menjadi bawah perhatiaan guru, berdasarkan observasi yang dilakukan maka pada siklus pertama memperoleh $63,98 \%$ d engan kategori "cukup" kemudian pada siklus II mengalami peningkatan menjadi $86,92 \%$ dengan kategori "baik", maka dalam hal ini telah mencapai indikator keberhasilan yang telah ditetapkan.

Penelitian ini berakhir setelah pelaksanaan siklus II karena telah mencapai indikator keberhasilan yang telah ditetapkan yaitu $80 \%$. Skenario pembelajaran yang dibuat telah terlaksana dengan benar.Model pembelajaran Treffinger ini memiliki kelemahan dan kelebihan karena materi pelajaran hanya bisa dilanjutkan kalau $80 \%$ siswa telah menguasai materi ajar. Selain itu dengan menggunakan model pembelajaran Treffinger siswa menjadi lebih aktif dan suasana belajar yang menyenangkan dan tercipta semangat siswa untuk mengemukakan pendapatnya. Sedangkan kelemahannya adalah menambah tugas guru dalam mengadakan perbaikan siswa yang tidak tuntas dan pengayaan bagi yang tuntas, selain itu pembelajaran ini juga tidak ditentukan berapa kali harus mengadakan perbaikan siswa yang tidak lulus yang menjadi patokan hanya $80 \%$ siswa menguasai materi baru bisa dilanjutkan kemateri baru.

\section{SIMPULAN}

Berdasarkan tujuan penelitian, hasil penelitian dan pembahasan, maka penelitian yang dilaksanakan di SMA Negeri 1 Angkola Barat dapat disimpulkan sebagai berikut.

Penerapan model pembelajaran Treffinger dapat meningkatkan kemampuan guru dalam mengelola pembelajaran. Dilihat dari hasil observasi kemampuan guru dalam mengelola pembelajaran pada siklus I memperoleh rata-rata persentase sebesar $64,00 \%$ dan meningkat sebesar $19,00 \%$ menjadi $83,00 \%$ pada siklus II.

Penerapan model pembelajaran Treffinger dapat meningkatkan pemahaman konsep siswa dalam belajar matematika siswa di kelasX $X_{5}$ SMA Negeri 1 Angkola Barat. Hal ini dapat ditunjukkan dengan hasil evaluasi pemahaman konsep matematika siswa yaitu28,94\% dan meningkat sebesar $52,63 \%$ menjadi $81,39 \%$ pada siklus II.

Penerapan model pembelajaran Treffinger dapat meningkatkan disposisi matematis siswa dalam belajar matematika siswa di kelas $\mathrm{X}_{5}$ SMA Negeri 1 Angkola Barat. Hal ini dapat ditunjukkan dengan hasil evaluasi pemahaman konsep matematika siswa yaitu $31,31 \%$ dan meningkat sebesar50,26 \% menjadi $81,57 \%$ pada siklus II.

Penerapan model pembelajaran Treffinger dapat meningkatkan aktivitas siswa terhadap pelajaran matematika di kelas $\mathrm{X}_{5}$ SMA Negeri 1 Angkola Barat. Dilihat dari hasil observasi aktivitas siswa pada siklus I diperoleh persentase rata-rata kadar aktivitas siswa sebesar 
$63,98 \%$ selanjutnya persentase rata-rata kadar aktivitas siswa pada pelajaran matematika meningkat sebesar $22,94 \%$ menjadi $86,92 \%$ pada siklus II.

\section{DAFTAR PUSTAKA}

Arikunto, Suharsimi. 2015. Dasar-dasar Evaluasi Pendidikan. Jakarta: Bumi Aksara.

Depdiknas. 2003. Kurikulum 2004 Standar Kompetensi Sekolah Dasar. Jakarta : Depdiknas.

Mulyatiningsih, Endang. 2011. Metode Penelitian Terapan Bidang Pendidikan. Yogyakarta: Alfabeta.

Ngalimun. 2014. Strategi dan Model Pembelajaran. Aswaja pressindo. Yogyakarta.
Sudijono, Anas. 2008. Pengantar Evaluasi Pendidikan. Jakarta: Raja Grafindo Persada 1996.Sumarmo, Utari. 2010. Berpikir dan Disposisi Matematik: Apa, Mengapa, dan Bagaimana Dikembangkan pada Peserta Didik. Artikel pada FPMIPA UPI Bandung.

Shoimin, Aris. 2014. 68 Model Pembelajaran Inovatif dalam Kurikulum 2013. Yogyakarta: Ar-Ruzz Media.

Wardani, S. 2009. Meningkatkan kemampuan berfikir kreatif dan disposisi matematik siswa SMA melalui pembelajaran dengan pendekatan model Sylver. Disertasi doktor, tidak diterbitkan. Sekolah Pascasarjana Universitas Pendidikan Indonesia: Bandung. 